\title{
Seni Lukis Modern Bernafaskan Islam di Bandung 1970-2000an
}

\author{
Agus Cahyana, Reiza D. Dienaputra, Setiawan Sabana, Awaludin Nugraha \\ Program Studi Ilmu Sejarah Fakultas Ilmu Budaya \\ Universitas Padjajaran \\ Jalan Raya Bandung Sumedan Km. 21 Jatinangor \\ cahayana@gmail.com
}

\begin{abstract}
Writing the history of the development of modern Indonesian painting from thematic point of view still refers to importance events that compose the mainstream of contemporary art trends in Indonesia influenced by the West. While events that are no less important relating to the emergence of aesthetic tendencies related to religion have been marginalized, especially in modern art with Islamic breath become important part in the history of the development of modern Indonesian painting, aesthetic approach to analyze the visual elements present in the painting. The result of this study the development of modern Islamic art in Bandung shows that there are 4 period of development, the 70s, the 80s, the 90s, and 2000s. This division of time is based on thematic tendencies that emerge and became the main tendencies at each time.
\end{abstract}

Keywords: Painting, modern, Islam, Bandung

\begin{abstract}
ABSTRAK
Penulisan sejarah perkembangan seni lukis modern Indonesia dari sudut pandang tematikhingga saat ini masih mengacu pada peristiwa penting yang menggubah arus utama kecenderungan seni rupa kontemporer di Indonesia yang dipengaruhi Barat. Sementara peristiwa yang tidak kalah penting berkaitan dengan munculnya kecenderungan estetik yang berkaitan dengan agama menjadi terpinggirkan, khususnya dalam seni lukis modern bernafaskan Islam. Hal itu yang menjadi latar belakang penelitian ini dilakukan dengan tujuan agar perkembangan seni lukis modern bernafaskan Islam menjadi bagian penting dalam sejarah perkembangan seni lukis modern Indonesia khususnya di kota Bandung. Penelitian ini menggunakan metode sejarah visual yang tentu melibatkan pendekatan estetik untuk menganalisis unsur-unsur rupa yang hadir dalam lukisan. Hasil dari penelitian ini perkembangan seni lukis modern bernafaskan Islam di kota Bandung secara tematik menunjukkan bahwa terdapat 4 periode perkembangan, yaitu masa tahun 70-an, masa perkembangan di tahun 80-an, di tahun 90-an dan tahun 2000-an. Pembagian masa ini berdasarkan kecenderungan tematik yang muncul dan menjadi kecenderungan utama pada tiap masa.
\end{abstract}

Kata Kunci: Seni lukis, modern, Islam, Bandung

\section{PENDAHULUAN}

Penulisan sejarah seni rupa modern Islam di Indonesia, khususnya di bidang seni lukis Islam dapat dikatakan masih sangat sedikit, hal tersebut dapat dilihat dari bukubuku sejarah seni rupa modern Indonesia yang menjadikan seni lukis modern Indonesia bernafaskan Islam dari sudut historis sebagai kajian utama yang masih sangat jarang dilakukan. Pembahasan mengenai seni lukis modern bernafaskan Islam lebih banyak menuliskan sosok pelukis yang menampilkan 
unsur-unsur Islam dalam karyanya, dibanding membahasnya dalam konteks perkembangan seni lukis modern bernafaskan Islam di Indonesia secara runut.

Sementara itu di Barat sendiri minat terhadap penelitian seni rupa Islam modern semakin meningkat, terutama pada periode setelah Perang Dunia II, seiring dengan munculnya kekuatan ekonomi di negara di Timur Tengah yang menguasau cadangan minyak bumi yang berlimpah. Melalui kekuatan ekonomi yang besar, berbagai pameran budaya Islam diselenggarakan di Eropa dan Amerika, termasuk mendirikan pusat-pusat kajian budaya Islam di berbagai universitas. Koleksi artefak budaya Islam yang dikoleksi oleh berbagai museum di Eropa dan Amerika menjadi salah satu hal yang menarik perhatian para peneliti budaya Timur. Melihat fenomena tersebut, salah satu ahli sejarah Islam Amerika, Richard Ettinghausen dalam bukunya Islamic Art and Archaeology (1951) menyatakan bahwa Seni Muslim dan studinya akan memiliki peran penting untuk dilakukan di masa depan, hal ini didasarkan pada penghargaan yang begitu besar dari masyarakat Barat terhadap aktivitas kultural yang dilakukan oleh dunia Muslim, terutama yang dilakukan oleh negara kaya minyak di Timur Tengah. Prediksi tersebut ternyata terbukti di beberapa tahun terakhir.

The last decade has seen an increase in the number of publication about modern and contemporary issues in Islamic art, as well as a greater number of academic art historian positions that allow for modern non-western and Islamic specializations. (Shaw,2012, hlm. 10).

Dengan demikian penelitian tentang seni Islam modern semakin banyak dilakukan dan memberi ruang yang terbuka bagi para sejarawan seni Islam di Indonesia untuk mempublikasikan hasil penelitiannya. Hasil penelitian mengenai seni lukis modern bernafaskan Islam di Indonesia dapat menjadi salah satu model dari bagaimana ajaran Islam diimplementasikan ke dalam budaya Indonesia saat ini, khususnya di bidang seni lukis.

Membicarakan mengenai seni Islam, tentu akan terpusat pada hasil budaya Islam di kawasan Timur Tengah, yang dianggap sebagai pusat dari penyebaran budaya Islam. Sehingga buku-buku sejarah seni Islam yang ditulis lebih banyak menjelaskan mengenai perkembangan seni Islam di daerah ini yang kemudian menyebar ke daerah Eropa dan Asia Tengah. Oleh karena itu tidak mengherankan apabila puncak-puncak pencapaian karya seni Islam di wilayah-wilayah tersebut menjadi tolok ukur bagi karya seni rupa Islam, seperti seni kaligrafi Arab, Arabesk, lukisan miniatur, hingga motif geometrik. Pada akhirnya seni rupa Islam identik dengah hadirnya ciriciri tersebut di atas. Hal ini tentu memicu perdebatan di kalangan para ahli sejarah seni Islam, yang berkaitan dengan pertanyaan apakah yang dimaksud dengan seni rupa Islam, mengingat pencapaian-pencapaian tersebut dihasilkan dari keberhasilan para perupa dalam menggabungkan unsur Persia, Bizantium, hingga Mogul ke dalam suatu bentuk perupaan yang sesuai dengan kaidah Islam dan kebijakan penguasa saat 
itu. Hal ini tentu berdampak pada penulisan sejarah seni rupa Islam modern di mana pencapaian tersebut menjadi tolok ukur dari perkembangan sejarah seni rupa Islam di luar wilayah Timur Tengah dan sekitarnya.

Dengan demikian apakah seni rupa Islam berkaitan dengan tempat di mana ia tumbuh atau berkaitan dengan gaya dan bentuk yang menjadi ciri seni rupa Islam masa klasik. Merujuk pada pendapat Choudhrey dan Bobrowich, yang mengkategorikan seni Islam secara umum, yaitu "(1) the identification of the locationing which an artwork was made, (2) the time or era in which it was made, and (3) the presence of an Islamic culture in the form of a Muslim population or a Muslim ruler/patron at the location in which it was made. Dengan merujuk pada pendapat ketiga, maka seni rupa Islam Indonesia hadir dikarenakan mayoritas masyarakat Indonesia beragama Islam sehingga terbentuk budaya Islam yang khas Indonesia, baik di masa kejayaan kerajaan Islam di Indonesia, maupun di masa modern. Mengenai keunikan sebaran Islam di Indonesia yang berbeda dengan di wilayah lain menandakan bahwa penerapan ajaran Islam pada tiap budaya mempunyai cara tersendiri dan bersifat dinamis sesuai kebutuhan wilayahnya.

“...it important to recognize that one cannot assume that Islam as it is practiced in one geographical and chronological frame is practiced in the same manner elsewhere or at a different time. Religion, like history, is dynamic." (Asher , 2015, hlm. 23)
Pada penelitian mengenai seni modern bernafaskan Islam, penulis menggunakan istilah senilukis modern Indonesia bernafaskan Islam bukan seni lukis Islam modern, ditujukan untuk menunjukkan bahwa seni lukis modern Indonesia muncul dan berkembang karena pengaruh Barat melalui kolonialisme, yang tidak berhubungan dengan perkembangan seni lukis Islam klasik, baik yang berasal dari Timur Tengah maupun masa kerajaan Islam di Indonesia. Dengan demikian seni lukis modern Indonesia yang berkembang semasa Raden Saleh dapat dikatakan bukan kelanjutan dari seni lukis tradisi yang telah ada sebelumnya, termasuk didalamnya seni lukis Islam. Dengan demikian penggunaan bernafaskan Islam ditujukan terhadap seni lukis modern Indonesia yang mengungkapkan nafas islam pada tiap lukisannya, yang mungkin saja mengambil ciri utama dari seni Islam yang telah dikenal secara umum.

Berkaitan dengan penulisan perkembangan seni lukis modern Indonesia bernafaskan Islam di Bandung ternyata belum terpetakan secara baik dan utuh, sehingga diperlukan penelitan yang mampu mengintegrasikan secara komprehensif semua kecenderungan tematik yang muncul pada setiap karya. Berdasarkan hal itu diperlukan pengumpulan data dari penelitian sebelumnya yang sebagian besar dilakukan oleh akademisi, baik dalam bentuk skripsi, tesis, maupun disertasi serta para kurator yang memberi kurasi pada setiap pameran yang dirancangnya.

Sumber data yang menjadi penting dalam penelitian ini, selain dari hasil studi 
mahasiswa, juga berasal dari katalog-katalog pameran seni rupa bernafaskan Islam, mulai dari tahun 70-an hingga sekarang. Sumber katalog ini menjadi sangat penting, karena melalui katalog inilah sebetulnya pengklasifikasian seni lukis bernafaskan Islam telah dilakukan. Melalui tulisan kurator dalam tiap katalog dijelaskan mengenai nafas Islam yang tercakup dalam tiap lukisan yang dipamerkan. Pada tulisan ini akan dipaparkan mengenai perkembangan seni lukis modern Indonesia bernafaskan Islam di Bandung dari tahun 1970-2020 ditinjau dari sudut perkembangan tematik dalam tiap lukisan. Dengan dibatasi pada permasalah tematik lukisan, diharapkan mampu menggambarkan perkembangan secara lebih terperinci.

\section{METODE}

Penelitian ini dilakukan dengan menggunakan metode sejarah sebagai cara untuk mengetahui perkembangan estetik seni lukis modern bernafaskan Islam di kota Bandung tahun 1970-2020. Adapun tahapan yang dilakukan adalah tahap pertama adalah pengumpulan data atau heuristik yaitu tahapan mencari sumber-sumber untuk mendapatkan data, mulai dari buku, katalog, disertasi, dan melihat secara langsung lukisan yang menjadi obyek kajian. Berikutnya adalah tahap kritis, yaitu menganalisa data yang telah didapatkan sesuai dengan yang diperlukan dan dapat dipertanggungjawabkan. Pada tahap akhir adalah tahap interpretasi atau penafsiran dengan mengacu pada konteks karya dihubungkan dengan aspek tema yang terdapat dalam lukisan.

Dalam mengintepretasikan data, maka pendekatan estetika yang berkaitan dengan tema, konsep, dan unsu-unsur rupa yang terdapat dalam karya lukis. Penelitian mengenai perkembangan tema dalam karya seni lukis modern tentu berkaitan erat dengan analisa sumber visual, dalam hal ini adalah lukisan. melalui analisis terhadap unsur visual dalam lukisan maka sejarah perkembangan seni lukis modern bernafaskan Islam dapat dipaparkan secara utuh. Untuk itu dalam menganalisis sumber visual menggunakan konstruk sejarah visual sebagai acuannya.

sejarah visual merupakan hasil rekonstruksi sejarah yang berbasiskan pada penggunaan sumber-sumber visual atau menjadikan sumber visual sebagai sumber utama dalam rekonstruksi sejarah. Dengan pengertian seperti ini, maka karya sejarah yang berkonstruk sejarah visual secara substansial akan kaya dengan gambar, baik bergerak maupun tidak bergerak, serta (atau) kaya akan deskripsi dan analisis yang berbasiskan fakta visual. (Dienaputra, 2012, hlm. 11)

Melalui analisis dan interpretasi terhadap sumber visual berupa lukisan yang bernafaskan Islam dari tahun 1970-2020, maka akan terlihat perkembangan seni lukis modern bernafaskan Islam dari tahun 1970-an hingga tahun 2000-an mempunyai kecederungan tematik yang khas.

Berkaitan dengan sejarah visual sebagai sebuah metode, maka terdapat beberapa pertanyaan yang menjadi dasar dalam menganalisis data seperti yang dikemukakan 
Claus (2017, hlm. 294) yaitu mencakup 3 tema yang muncul. pertanyaan sebagai berikut :

1. How, when, why, and by whome was image create?

2. How does the image relate to the historical reality it seeks to represent?

3. How was the image perceived by contemporary observers?

Pertanyaan tersebut walaupun tidak secara terperinci dapat diterapkan, namun memberikan arahan dalam menganalisa dan menginterpretasikan tema yang terdapat dalam karya seni modern Indonesia bernafaskan Islam ini.

Sedangkan untuk menjelaskan perkembangan secara tematik, maka dilakukan periodisasi sepuluh tahunan, hal ini juga berkaitan dengan munculnya kecenderungan tematik yang juga terjadi dalam kurun periodisasi tersebut. Yaitu peiode pertama tahun 1970-an, periode kedua tahun 1980-an, periode ketiga tahun 1990-an, dan periode keempat tahun 2000-an.

\section{HASIL DAN PEMBAHASAN}

Paparan mengenai pembahasan seni lukis modern bernafaskan Islam Indonesia dimulai dengan membuat periodisasi waktu yang berkaitan dengan peristiwa atau hal penting yang terjadi dalam kurun waktu tersebut. Dengan mempertimbangkan hal tersebut maka dalam penelitian ini membagi perkembangan ke dalam 4 kategori waktu, yaitu tahun 1970an,1980an, 1990an, dan 2000an. Dengan demikian memudahkan untuk mengidentifikasi tiap kecenderungan

\section{Periode Tahun 1970-1980 an}

Perkembangan seni lukis modern bernafaskan Islam di kota Bandung ditandai dengan hadirnya unsur kaligrafi dalam karya seni lukis Ahmad Sadali dan A.D. Pirous, yang keduanya dikenal sebagai seniman modernis. Munculnya unsur kaligrafi yang menjadi penanda kehadiran nafas Islam dalam seni lukis modern di Bandung. Abdul Hadi W.M. (2000, hlm. 392) menyatakan bahwa munculnya kaligrafi dalam seni lukis modern di tahun 70-an menandai munculnya gerakan Seni Rupa Islam Kontemporer di Indonesia.

Pencapain kedua pelukis hingga memutuskan untuk menampilkan spirit Islam dalam karya mereka tidaklah terjadi secara tiba-tiba, tetapi melalui proses yang bertahap, mulai dari mempelajari seni rupa modern Barat hingga akhirnya timbul kesadaran sebagai orang Indonesia yang beragam Islam harus menampilkan identitas yang mampu menggabungkan antara seni modern dengan keyakinan agama yang dianutnya. Diawali melukis dengan cara pandang Barat, kedua seniman ini merasakan kebebasan untuk berekspresi secara menyeluruh dalam megolah unsur rupa dengan prinsip seni modern Barat. Akan tetapi perlakuan Barat yang menganggap seni modern di luar Barat bukan menjadi bagian dari seni rupa modern Barat, karena hanya sebatas melakukan peniruan semata. Mendorong para seniman untuk terus mencari keunikan pada karya mereka, salah satunya yaitu dengan mencari ke wilayah budaya, termasuk pada agama 
yang mereka yakini.

Proses pembelajaran seni modern yang hampir sama antara Ahmad Sadali dan A.D. Pirous, membuat proses penemuan yang memunculkan nafas Islam dalam karya mereka berjalan hampir sama. Hal tersebut dapat dilihat dari jejak-jejak kekaryaan mereka dari mulai studi hingga akhirnya berhasil membuat karya yang memunculkan identitas mereka yang unik, Ahmad Sadali dengan gaya abstrak meditatif dan A.D. Pirous dengan karya seni lukis kaligrafi Islamnya sebagai hal utama dalam karya-karyanya.

Ahmad Sadali melalui lukisannya yang cenderung menghadirkan warna-warna yang memiliki kualitas kedalaman, seperti nuansa warna coklat hingga biru keungu-unguan serta penggunaan warna emas yang seperti meleleh membawa kesan tenang, sepi, dan meditatif. Hal itu diperkuat dengan permainan tekstur yang seperti menghadirkan kesan tua dan lapuk, sehingga membawa apresiator untuk masuk ke wilayah perenungan tentang kefanaan. Adapun hadirnya kaligrafi dan bentuk segitiga yang seperti bentuk gunungan menjadi simbol kemusliman yang selalu menjaga hubungannya dengan Sang Pencipta. Sadali berhasil memadukan bahasa rupa yang murni - yakni garis, warna, bentuk, dan bidang - dengan lambag-lambang imajinatif yang dapat menggerakkan dan menggetarkan jiwa. (Hadi, 2000, hlm. 403).

Melalui kemampuan menggabungkan berbagai unsur rupa dengan lambang imajinatif serta kaligrafi pada lukisannya, membuat karya Ahmad Sadali mampu mendorong apresiator ke dalam ruang

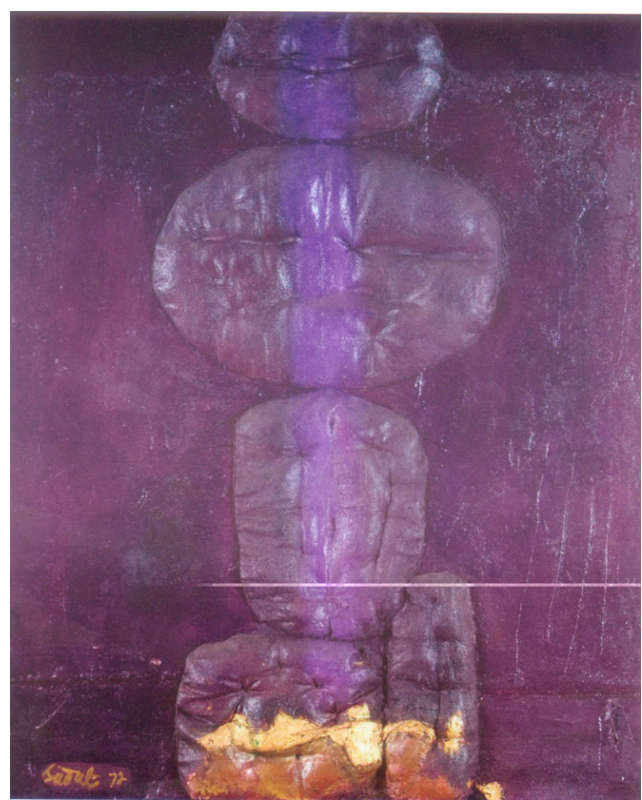

Gambar 1: Ahamd Sadali “Emas pada Relief Ungu”, 1972 Mixed media di kanvas,

Sumber : Katalog Pameran Islam and Identity, 2009

perenungan tentang kefanaan sekaligus mengingat mengenai kekuasaan Allah SWT, menjadikan lukisannya dapat dikatakan sebagai media untuk menyebarkan muatan spiritual yang universal terlepas dari agama yang melatarbelakanginya.

“Objek-objek estetis berhasil ditingkatkan menjadi sarana renungan metafisis. Dengan cara demikian lukisan-lukisannya mengantarkan jiwa penikmatnya ke wilayah pengalaman lain yang tidak dijumpai dalam keberadaan rutin kita sehari-hari, yaitu pengalaman kekariban hati manusia dengan alam kerohanian, yang merupakan pancaran alam ketuhanan". (Hadi, 2000, hlm. 403)

Kehadiran kaligrafi pada lukisan Ahmad Sadali menjadi salah unsur yang semakin memperkuat kesan tersebut, sekaligus menyatakan identitasnya sebagai seorang muslim yang mampu menghadirkan nafas Islam dalam karya seni lukis modernnya. Dengan kemampuan dan pencapaiannya 
tersebut dapat dikatakan bahwa "Ahmad Sadali mewakili generasi pertama pelukis akademis paling menonjol. Ia juga mewakili generasi Muslim Indonesia awal yang secara mengagumkan mampu menonjolkan kemusliman dirinya dalam perjumpaan dengan seni modern". (Hadi, 2000, hlm. 397)

Di samping Ahmad Sadali, kehadiran A.D. Pirous tidak kalah penting dalam perkembangan seni lukis modern bernafaskan Islam di Bandung. Latar belakangnya budaya Aceh menyebabkan mempunyai ikatan yang tinggi terhadap tanah kelahirannya. Kehidupan keagamaan yang kuat di Aceh menjadi pendorong untuk menampilkan identitas keislaman melalui karya-karyanya. Berbeda dengan Ahmad Sadali yang mengungkapkan unsur keislaman tidak selalu memakai teks kaligrafi, maka A.D. Pirous justru selalu menampilkan kaligrafi sebagai ciri utama dalam lukisannya. Arti ayat pada kaligrafi yang dihadirkan berkorelasi dengan unsur rupa yang ditampilkan. Sehingga teks kaligrafi ditafsirkan ke dalam unsur-unsur rupa dalam lukisan.

Perjalanan A.D. Pirous dalam berkarya hampir serupa dengan Ahmad Sadali, ia memulai dengan estetika modern yang cenderung bergaya abstrak dan kubistis sebagai landasan berkarya, seperti pada umumnya yang diajarkan di seni rupa ITB oleh para guru-guru Eropa pada tahun 1960an. Dengan melukis dengan cara Barat dan modernisme sebagai dasar pemikirannya menjadikan seorang seniman dapat diterima sebagai bagian dari seniman global yang bersifat universal, hal ini pula yang dialami

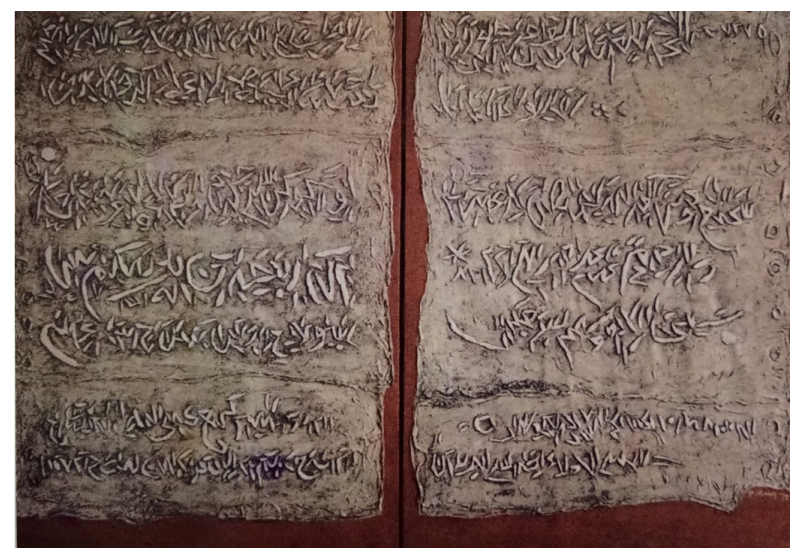

Gambar 2 : A.D. Pirous, “White Writing”1972 $100 \times 180 \mathrm{~cm}$ pasta marmer, acrylic di kanvas

oleh A.D. Pirous. Pandangan tersebut berubah ketika ia mendapatkan kesempatan untuk belajar ke kota pusat seni modern dunia, yaitu New York, dimana justru ia dihadapkan pada realitas bahwa keberadaan seni modern yang bersifat universal itu tidak ada. Hal itu diungkapkan Pirous dalam buku yang ditulis oleh Kenneth M. George :

“Setiap kali pergi ke New York City untuk mengunjungi museum, dia selalu meminta kepada pihak sponsor untuk menunjukkan tempat dimana dia dapat melihat seni Asia kontemporer, khususnya seni kontemporer Indonesia. Seperti yang dikatakan oleh Pirous, dia selalu mendapatkan jawaban yang sama: “Tidak, Belum ada kategori untuk itu (seni Asia kontenporer). Jika yang Anda maksudkan adalah seni rakyat, seni tradisional, seni primitif, seni etnis, ada. Tapi jika yang Anda maksudkan adalah seni modern, seni kontemporer, tidak ada". Indonesia dan, tentu saja, kebanyakan negara di Asia belum diakui oleh para kurator dan kritikus seni sebagai negeri yang mampu memproduksi seni modern. (George, 2010, 
hlm. 64-65)

Paham universal yang diagungkan dalam seni modern ternyata hanya berlaku bagi negara-negara Barat, sehingga dengan kejadian tersebut memunculkan kesadaran untuk menghadirkan jati diri sebagai seorang seniman Indonesia di tengah arus modernitas global. Salah satu cara yang dilakukannya adalah dengan kembali melihat asal usul budaya dimana ia tumbuh dan berkembang, yaitu dalam lingkungan masyarakat Aceh yang lekat dengan budaya Islam. Kesadaran itu justru muncul ketika A.D. Pirous berada di New York dan dihadapkan pada kekecewaan mengenai situasi seni modern dunia yang ia yakini bersifat universal. Ketika saya berada di New York, dan kebetulan saya melihat dan menemukan warisan Islam, saya berkata, “Wah ini dia" Tiba-tiba muncul lagi. "Ini, ini milik saya, ini harta saya." (George, 2010, hlm. 67). Keadaan ini menjadi titik balik dari perjalanan karya A.D. Pirous, yang memutuskan untuk membuat karya yang berangkat dari spirit al-Quran, yakni etsa kaligrafi Surah Al-Ikhlas pada tahun 1970 yang dibuat di New York.

Pameran "Group 8" di Taman Ismail Marzuki (TIM) Jakarta yang diselenggarakan pada tahun 1971, memunculkan pengakuan terhadap lukisan kaligrafi modern, yang ditandai oleh dipamerkannya 7 lukisan kaligrafi A.D. Pirous yang mendapat sambutan positif maupun kritik tajam. Terlepas dari hal itu, melalui karya lukisan kaligrafinya tersebut, A.D. Pirous telah membuat kecenderungan baru dalam seni lukis modern Indonesia. Setahun kemudian
A.D. Pirous membuat pameran tunggal di Chase Manhattan Bank Program, Jakarta, pada tahun 1972, yang menampilkan karya-karya kaligrafi modern Islam. Unsur kaligrafi pada pameran ini berbeda dengan karya pertama yang menampilkan surat al-Ikhlas secara jelas dan dapat dibaca dengan baik, pada pameran ini unsur keterbacaan bukan hal yang utama. Unsur kaligrafi yang berkesan huruf 'Arab' hanya berupa bentuk-bentuk yang menyerupai atau sepintas mengingatkan kita pada kaligrafi Mesir Kuno (hieroglif). (George dan Mamannoor, 2002, hlm. 164)

Pada perkembangan karya selanjutnya, perlakuan terhadap kaligrafi menjadi berbeda dimana unsur kaligrafi tidak hanya tampil sebagai unsur rupa yang menjadi unsur pelengkap dalam struktur komposisi lukisan abstrak, sehigga mengesampingkan unsur keterbacaannya, melainkan menjadi unsur terpenting dimana setiap ayat yang dihadirkan dapat terbaca dengan jelas. Dengan demikian apresiator dapat membaca dengan jelas setiap ayat yang dihadirkan dalam lukisan, sementara unsur-unsur rupa lainnya menjadi satu kesatuan yang mendukung makna dari keberadaan ayat dalam lukisan. Perubahan ini terjadi didorong oleh keinginan A.D. Pirous agar orang lain dapat lebih mengerti mengenai maksud dari ayat yang ditampilkan dalam lukisannya, sehingga melalui lukisannya ia dapat memberi manfaat bagi orang lain bukan hanya masalah kepuasan berekspresi pribadi semata.

"So, I sacrificed myself, saya batasi ekspresi-ekspresi bebas saya itu, tapi saya 
kembalikan kepada nilai-nilai yang saya bisa gali secara lebih banyak dan secara lebih berbobot dari Al-Qur'an itu sendiri... Saya menanam ke dalam lukisan-lukisannya suatu konsep berfikir atau suatu nilai-nilai lain yang filosofis, yang membuat orang itu bisa lebih menikmatinya. "Aesthetic pleasure dan ethical pleasure together." (George dan Mamannoor, 2002, hlm. 59-60)

Kehadiran A.D. Pirous dengan lukisan kaligrafi yang mulai diperkenalkan melalui pameran bersama di tahun 1971 dan pameran tunggal di tahun 1972, dimana mendapat tanggapan cukup baik, mendorongnya untuk terus menghadirkan lukisan kaligrafi dalam setiap pameran yang diikutinya. Hasilnya adalah istilah lukisan kaligrafi menjadi salah kecenderungan dalam seni lukis modern Indonesia mulai diakui dan diikuti oleh para pelukis lainnya, seperti Amri Yahya, Amang Rahman, Syaiful Adnan, Hatta Hambali, Damas, Abay D. Subarna, Batara Lubis dan lain-lain.

\section{Periode Tahun 1980-an}

Memasuki tahun 1980-an perkembangan seni lukis modern Islam di Bandung masih sangat dipengaruhi oleh gaya abstrak yang digabungkan dengan unsur kaligrafi Islam. Selain itu kecenderungan penggunaan tekstur dari bubuk marmer dan penggunaan warna emas serta bentuk simbolik semakin kuat terlihat pada karya Ahmad Sadali. Sedangkan A.D. Pirous, pada tahun 80-an ini lebih banyak mengeksplorasi unsur rupa yang

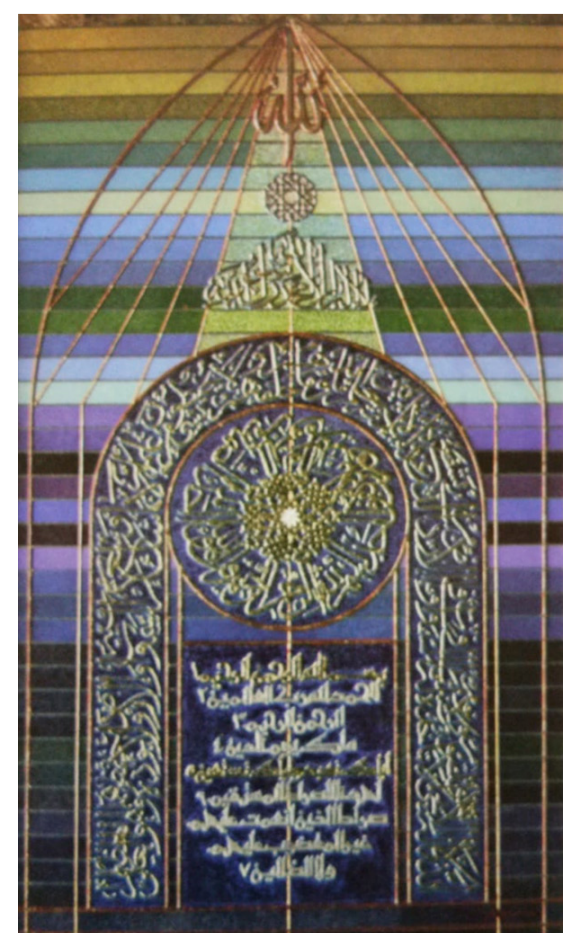

Gambar 1: Abay D. Subarna, Lengkung Mihrab Transendental, 2009 Akrilik di kanvas, 200x110 cm

berasal dari budaya Aceh, karena menurutnya masih banyak nilai estetika Aceh yang belum terungkap dengan cara menggali nilai-nilai dekoratif, nilai-nilai bahasa visual yang ada di Aceh, yang terdapat, yang terungkap di dalam benda-benda yang dibuat oleh orang-orang Aceh, masyarakat Aceh untuk kehidupan mereka sebagai unsur budaya (George dan Mamannoor,2002, hlm. 81)

Pelukis Bandung lainnya yang menampilkan kaligrafi pada karyanya yaitu Abay D. Subarna, yang menyajikan kaligrafi Arab berupa ayat atau surat yang ada dalam Al-Qur'an, yang ditampilkan dengan gaya dekoratif. Berbeda dengan Ahmad Sadali dan A.D. Pirous, kaligrafi pada lukisan Abay D. Subarna dihadirkan dengan mengikuti kaidah khat penulisan seni kaligrafi yang formal, sehingga keindahan bentuk sesuai dengan khat yang dipakainya. Pertumbuhan ekonomi yang terus meningkat terutama di kalangan 
menengah atas memacu meningkatkan minat apresiasi terhadap karya seni rupa, khususnya seni lukis. Gaya abstrak yang menjadi simbol kemodernan banyak mendapat apresiasi yang cukup baik dari para peminat seni, khususnya para kolektor. Ahmad Sadali dengan lukisan abstrak meditatif yang bernuansa religiusitas Islam yang kuat menjadi salah satu pelukis yang karya-karyanya mendapat apresiasi yang tinggi dari para peminat seni di era ini. Keberhasilan Ahmad Sadali menggabungkan seni lukis modern dengan Islam memberi jalan bagi lahirnya seni lukis modern bernafaskan Islam di Indonesia.

Di era tahun 80-an ini perkembangan seni lukis modern bernafaskan islam di Bandung masih didominasi oleh gaya-gaya abstrak formalis dengan permainan komposisi unsur-unsur rupa seperti penggunaan unsur tekstur untuk menghadirkan kesan retakan, pelapukan, kekunoan, kekuatan hingga kesan kemegahan dan lain sebagainya, digabungkan dengan unsur kaligrafi Islam sebagai ciri utamanya. Dengan demikian tema kaligrafi menjadi salah ciri utama dalam perkembangan seni lukis modern bernafaskan Islam saat ini.

\section{Periode Tahun 1990-an}

Awal tahun 90-an menjadi momentum bagi perkembangan seni budaya Islam di Indonesia, ditandai dengan diselenggarakannya Festival Istiqlal I tahun 1991 dan Festival Istiqlal II tahun 1995 yang memperlihatkan keragaman budaya Islam Indonesia dan mancanegara. Melalui Festival Istiqlal inilah berbagai kecenderungan estetik seni lukis bernafaskan Islam dihadirkan, mulai dari lukisan kaligrafi hingga representasional. Semuanya dalam konteks menghadirkan nafas Islam ke dalam karya seni lukis yang berkembang saat ini. Melalui Festival Istiqlal yang telah dikunjungi oleh lebih dari 2 juta pengunjung inilah masyarakat umum mulai mengetahui mengenai bagaimana nafas Islam dihadirkan melalui karya seni lukis modern. Bagi pemerintah sendiri, festival ini merupakan bentuk dukungan serta kepedulian pemerintah dalam memajukan budaya Islam di Indonesia. Hal tersebut sebagaimana ditegaskan oleh Zaenudin Ramli dalam tulisannya di jurnal seni rupa Atrat sebagai berikut :

Praktik seni rupa modern dan kontemporer Islam di Indonesia yang dimulai pada tahun 1970an, sampai kini terus menunjukkan arah perkembangan. Titik puncak arah perkembangan seni Islam itu pada skala besar kemudian terrefleksikan pada Festival Istiqlal I 1991 dan Festival Istiqlal II 1995. Bagaimana pun juga masalah ekspresi estetik seni Islam di Indonesia sesungguhnya berbeda dengan ekspresi estetik di negara-negara muslim lainnya, begitu pun sebaliknya. Ada situasi factor sejarah budaya dan social yang jelas berbeda menaungi terhadap masalah tersebut. Dasar dari masalah ini, bertumpu pada keyakinan bahwa ekspresi estetik seni Islam yang berlaku di negaranegara muslim tersebut, hanyalah bagian dari ekspresi kultural yang meniscayakan perbedaan satu-sama lain. Disitulah 
perlu ditekankan, perbedaan bukan pada nilai Islam yang diacunya, melainkan perbedaan pada ekspresi kultural yang terjadi di masing-masing negara atau kawasan muslim. Seni rupa Islam kontemporer akan terus berjalan dari yang bentuk sederhana ke ekspresi yang kompleks, dalam seni dua dimensi yang nampak datar, lukisan, drawing, patung, object, video, dan instalasi. Dari tema-tema yang berpokok pada religi sampai pokok social-identitas, baik yang menyoal isu-isu yang berada di Barat atau di dunia Islam itu sendiri. (Vol 1, No 2 (2013) hal. 101)

Salah satu keberhasilan lainnya dari Festival Istiqlal I dan II adalah semakin berkembangnya interpretasi maupun apresiasi terhadap seni lukis modern Indonesia bernafaskan Islam, dimana nafas Islam dihadirkan dengan berbagai kecenderungan tematik. Bila pada tahun 70-80an tema lukisan bernafaskan Islam identik dengan kaligrafi Islam, maka pada festival Istiqlal, seni lukis modern bernafaskan Islam dikelompokkan menjadi 3 kecenderungan tematik, yaitu :

1. Lukisan Kaligrafi Arab

2. Lukisan Representasional

3. Lukisan Non-representasional

Pada lukisan bertema kaligrafi Arab, dihadirkan dalam bentuk penyampaian kembali petikan-petikan ayat (firman Allah dari Al-Qur'an) atau hadits, serta ungkapanungkapan sufistik. Penghadiran kaligrafi ini ditampilkan secara mandiri maupun pemaduan dengan berbagai kemungkinan dengan mempertimbangkan segi estetik.
Seperti pada gambar 4 karya Sirojudin yang menampilkan kaligrafi berisi ayat kursi. Kedua adalah lukisan yang menampilkan tema represenasional, yaitu lukisan yang menghadirkan wujud nyata alam dan anasirnya (antromorfis, zoomorfis, dan biomorfis) serta benda buatan dalam situasi, kondisi, dan peristiwa tertentu dengan penampilan sebagai gaya pengungkapan dan berbagai media dan teknik. Salah satu contoh bisa dilihat pada gambar 5, lukisan Barli yang menampilkan tiga figur dengan pakaian khas wanita muslim. Ketiga, lukisan dengan tema non-representasional yaitu lukisan yang tidak menghadirkan wujud nyata alam dan anasirnya. Bentuk-bentuk karya nonrepresentasional pada umumnya merupakan ungkapan dari pancaran (manifestasi) wujud nyata yang mengalami proses pendalaman terhadap kandungan makna (abstraksi) dan pengungkapan estetik. Penghadiran unsur abstraksi dapat berupa perlambangan (simbolik) ungkapan batin (ekspresi), dan sama searala mujarad (abstrak), dapat dilihat pada gambar 6 di karya Acep Zamzam Noor berjudul Ikan-ikan.

Luasnya cakupan tema dalam pameran Festival Istiqlal ini memberikan kebebasan bagi pelukis muslim untuk mengekspresikan nafas Islam ke dalam tema yang sesuai dengan ketertarikannya. Dengan demikian, pandangan yang selama ini melihat seni lukis bernafaskan Islam harus menampilkan kaligrafi Arab sebagai ciri utama keislaman menjadi lebih cair dalam pemaknaannya, nilai Islam bisa di interpretasikan ke dalam beragam bentuk perupaan sepanjang hal itu 


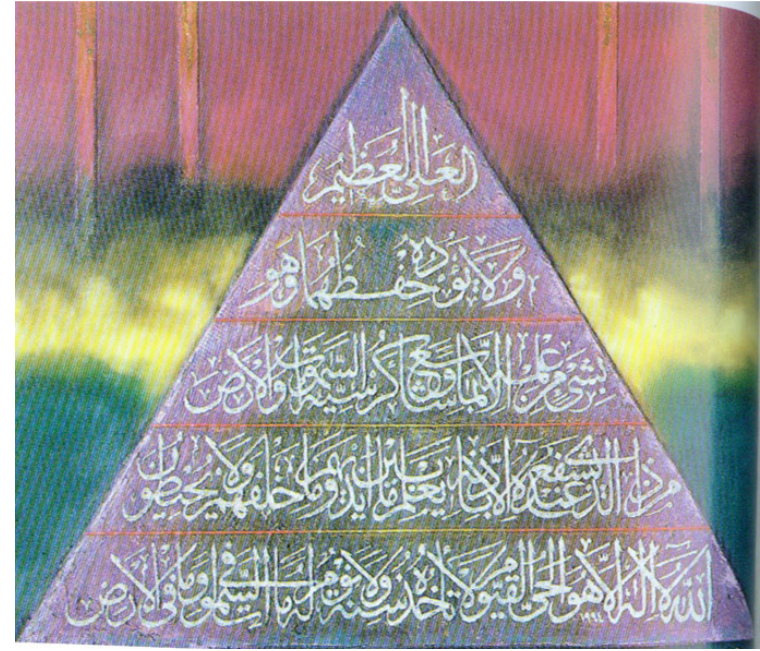

Gambar 4: D Sirodjuddin "Ayat Kursi", 1994 cat minyak di kanvas $130 \times 100 \mathrm{~cm}$ Sumber : Katalog Seni Rupa Kontemporer Festival Istiqlal Jakarta, 1995

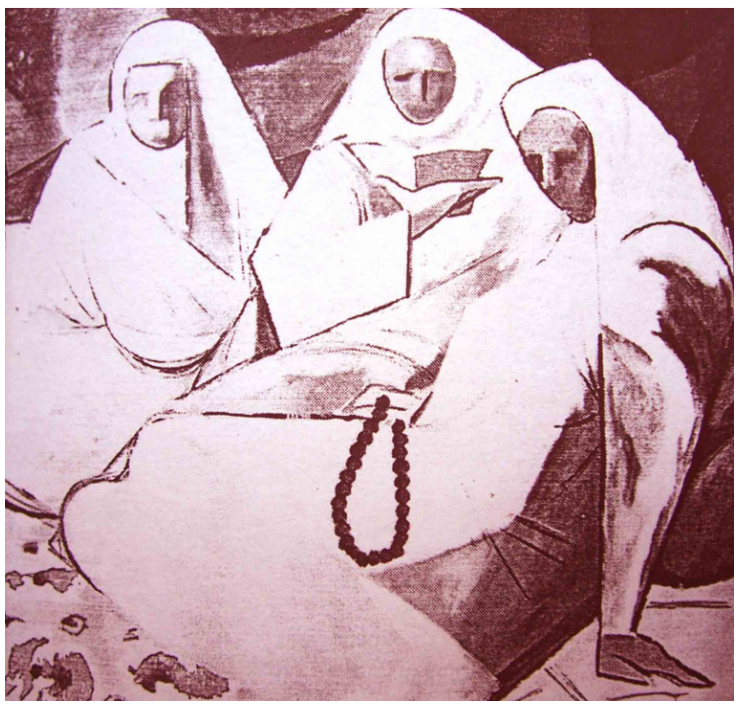

Gambar 5: Barli “Membaca Al-Qur'an” 1991 Cat minyak di kanvas, $145 \times 125 \mathrm{~cm}$, cat Sumber : Katalog Festival Istiqlal I, 1991

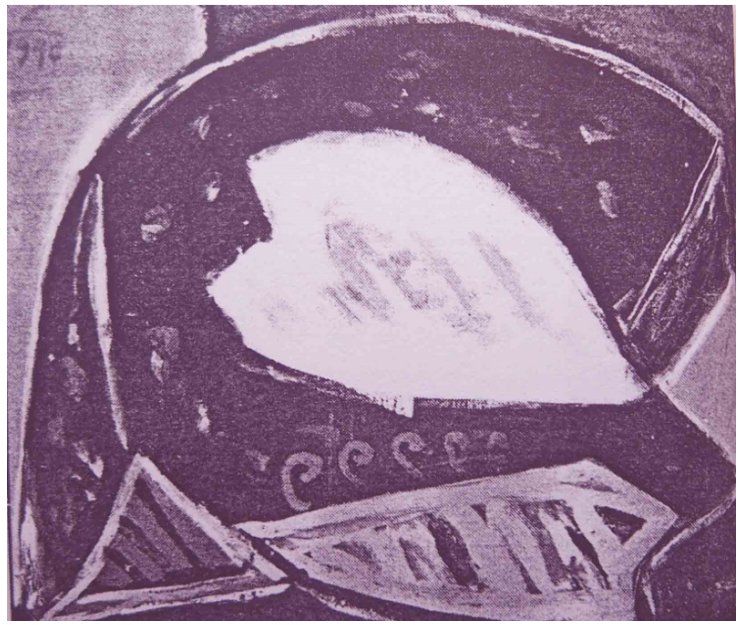

Gambar 6: Acep Zamzam Noor “Ikan-ikan” 1990 Akrilik di kanvas, 80x100 cm

(Sumber : Katalog Festival Istiqlal I, 1991) tidak bertentangan dengan syariat yang telah ditentukan dalam ajaran Islam. Demikian juga perdebatan mengenai penggambaran mahluk bernyawa dalam seni lukis modern bernafaskan Islam di Indonesia menjadi lebih terbuka, dan memberikan kebebasan bagi pelukis muslim untuk menentukan sikapnya. Semua pemikiran tentang seni bernafaskan Islam dipublikasikan oleh Yayasan Festival Istiqlal dalam bentuk buku berjudul Kebudayaan Islam, Dulu, Kini, dan Esok di tahun 1992, dan Ruh Islam Dalam Budaya Bangsa terbit tahun 1996. Dari kedua buku tersebut setidaknya permasalahan hubungan Islam dan seni dapat terjelaskan, walaupun tidak secara langsung membuat pada definisidefinisi atau batasan yang ajeg tentang seni (lukis) bernafaskan Islam.

Selepas festival Istiqlal I dan II, perkembangan seni lukis bernafaskan Islam seperti mengalami penurunan atau bisa dikatakan stagnan. Hal ini dipicu oleh keadaan sosial politik yang berimbas pada kegiatan berkesenian. Diawali tahun 1998 yang merupakan puncak dari gerakan reformasi, menjadikan kukungan politis pada masa Orde Baru menjadi runtuh, masyarakat dihadapkan pada kebebasan yang sepertinya tidak terbatas. Hal ini mengakibatkan seniman mempunyai semangat untukmengekspresikan perasaannya secara bebas, sehingga banyak bermunculan karya seni lukis dengan kecenderungan yang baru. Seni lukis modern bernafaskan Islam sendiri seperti kehilangan patron, karena secara politis keberhasilan pameran festival Istiqlal karena didukung oleh politik kebudayaan pemerintah Orde 
Baru yang menginginkan dukungan dari umat Islam sekaligus menjadikan Islam sebagai identitas budaya Indonesia yang toleran.

Di tengah situasi di penghujung tahun 90-an, A.D. Pirous membuat karya lukis yang merupakan wujud dari ekspresi kekecewaan terhadap pemerintah Orde Baru terhadap Aceh. Ia melukis sosok Teuku Umar dengan kutipan surat dalam huruf Arab serta ditampilkan dengan goresan-goresan warna merah yang ekspresif, sehingga mengesankan seseorang yang terluka. Pada periode inilah lukisan bernafaskan Islam modern tidak hanya menampikan mengenai keagungan maupun perenungan terhadap yang Maha Kuasa, tetapi lukisan bernafaskan Islam ternyata dapat dihadirkan sebagai media untuk menyatakan kritik terhadap kekejaman penguasa.

\section{Periode Tahun 2000-an}

Memasuki tahun 2000-an yang masih diwarnai oleh semangat kebebasan, pameran yang mengusung tema seni rupa Islam di Bandung kembali muncul dengan semangat interpretasi yang lebih luwes tentang keislaman. Nafas Islam dihadirkan sesuai intepretasi pengalaman seniman secara personal dan dihadirkan sesuai dengan kecenderungan estetik yang ada pada saat ini, sehingga secara perupaan penggunaan ikon-ikon yang lekat dengan tradisi seni Islam mulai ditinggalkan ataupun dihadirkan dalam konteks yang berbeda. Semangat seni kontemporer yang menekankan pada aspek pluralitas memberikan ruang yang luas bagi para pelukis untuk mengintepretasikan nafas Islam dalam berbagai cara tanpa terikat dengan perupaan yang telah menjadi ciri khas seni Islam klasik.

Dapat dicatat terdapat 4 kegiatan pameran seni lukis bernafaskan yang berlangsung pada tahun 2000-an yang cukup banyak menarik perhatian publik, yaitu pameran Islam and Identity dalam Bazaar Art I 2009, Inside Islam dalam Bazaar Art II 2010 , Sign and After Contemporary Islamic Art di Lawangwangi, Bandung tahun 2010 dan terakhir adalah pameran Bayang : Pameran Besar Seni Rupa Kontemporer Islami, yang diselenggarkan di Galeri Nasional Indonesia, Jakarta pada tahun 2011. Dari keseluruhan pameran yang diselenggarakan digagas oleh kurator yang berasal dari Bandung, yaitu Zaenudin Ramli, Rizki A. Zaelani, dan A. Rikrik Kusmara. Demikian juga dengan peserta pameran sebagian besar berasal dari Bandung. Dengan demikian peran kota Bandung dalam perkembangan seni lukis modern bernafaskan Islam di Indonesia menjadi cukup penting. Di samping 4 pameran tersebut, terdapat satu pameran tunggal seni lukis kaligrafi karya Imam Chairul Basri pada tahun 2003 yang diselenggarakan di gedung GSG Masjid Salman ITB.

Pada pameran Islam and Identity: Islamic Modern \& Contemporary Art Indonesia yang diselenggarakan Ritz Carlton-Pasific Place Jakarta tanggal 27-30 Agustus 2009, memamerkan karya 23 seniman. Dalam tulisan kuratorialnya, Zaenudin Ramli menjelaskan mengenai konsep yang melatarbelakangi pameran ini.

Pada kesempatan kali ini pameran 
Islamic Art Special Section yang di gelar di Bazaar Art Jakarta 2009. Menampilkan karya-karya para seniman muslim Indonesia yang mengangkat Islam sebagai pokok representasi realitas yang jamak. Dalam karya-karya yang ditampilkan nilai Islam dieksplorasi sebagai isu identitas. Tidak hanya meliputi pokok spiritualitas Islam yang lebih sakral, tetapi nilai Islam yang melebar pada konteks yang profan; menyangkut berbagai hubungan pada persoalan tradisi, sosial dan kehidupan urban. (Ramli,2009:12)

Kemudian berkaitan dengan representasi nilai keislaman dalam karya, ia menjelaskan :

Saya pikir seni Islam tidak hanya meliputi bentuk karya seni yang mengandung aspek religiusitas Islam saja. Tetapi meliputi unsur-unsur bagaimana nilai-nilai Islam direpresentasikan pada karya seni rupa. Dalam konteks seperti itu Islam merupakan representasi budaya; nilai Islam tidak hanya dipahami sebagai hal melulu ritualitas simbolik agama saja, akan tetapi nilai Islam dipahami sebagai identitas sekaligus jalan hidup (way of life) secara kontekstual. (Ramli, 2009, hlm. 12)

Berdasarkan penjelasan di atas maka karya yang ditampilkan pada pameran ini mempunyai batasan yang sangat luas dalam menginterpretasikan nilai Islam, mulai dari yang menampilkan tema masih berkaitan langsung dengan identitas keislaman seperti kaligrafi ataupun bentuk representasi dari ritual ibadah dan tempat ibadah hingga

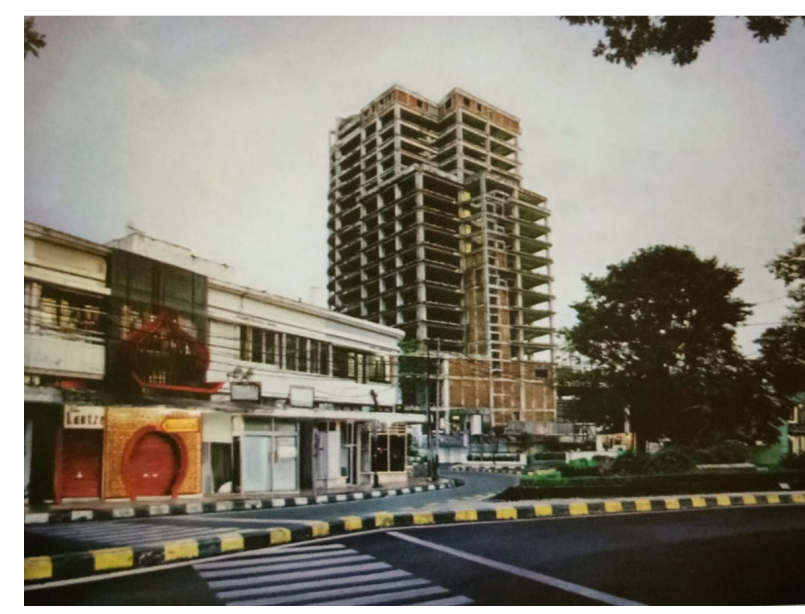

Gambar 7: Mariam Soprina, Mesjid Lautze, 2009 Cat Minyak di kanvas, $100 \times 130 \mathrm{~cm}$ Sumber : katalog Islam \& Identity

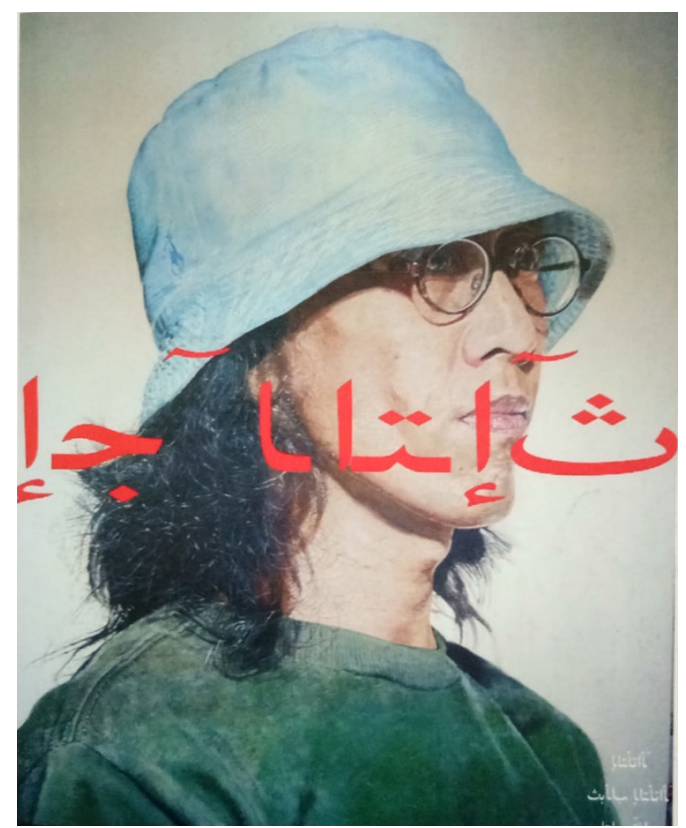

Gambar 8: Asmudjo, Islamicart Sumber: katalog Islam \& Identity, 2009

representasi keislaman dalam konteks kehidupan masyarakat urban yang dihadirkan oleh para seniman yang lebih muda. Hadirnya karya Ahmad Sadali dan A.D, Pirous pada pameran ini menunjukkan bahwa seni lukis modern bernafaskan Islam Indonesia tidak dapat dilepaskan dari peran mereka. Hal yang sama terlihat pada pameran Inside Islam dalam Bazaar Art II 2010, dimana karya Ahmad Sadali dan A.D. Pirous dihadirkan bersanding dengan karya Tisna Sanjaya dan Ahadiat Joedawinata. Bila melihat pada konteks 


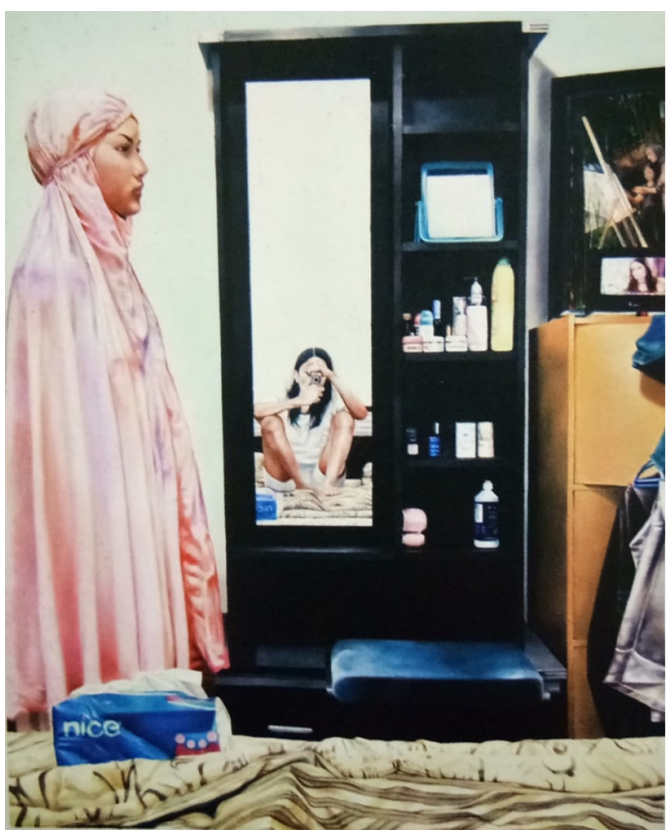

Gambar 8: Yogie A. Ginanjar, The Role of Husband \& Wife, 2009 Cat minyak di kanvas, $110 \times 80 \mathrm{~cm}$ Sumber: Katalog Islam \& Identity, 2009

pameran di Bazaar Art yang lebih menekankan sisi komersial, maka dapat disimpulkan bahwa nilai dari karya Ahmad Sadali dan A.D. Pirous masih cukup tinggi dan masih menjadi incaran para kolektor.

Pada kedua pameran tersebut memungkinkan seniman untuk lebih kreatif untuk mengembangkan tema yang akan diusung dalam karya, seperti pada karya Mariam Soprina yang menggambarkan masjid Lautse (Gambar 7) atau karya Asmudjo Jono Irianto (Gambar 8) yang menampilkan huruf Arab di depan wajah dirinya sebagai sebuah kritik terhadap kecenderungan kita yang mengidentikan Islam dengan Arab, demikian juga dengan hadirnya kaligrafi Arab dalam lukisan seolah-olah menjadi pengesahan bahwa karya tersebut termasuk dalam karya seni lukis Islam. Pada karya Yogie Ahmad Ginanjar, kecenderungan tema yang mencerminkan keseharian masyarakat saat ini ditampilkan secara apa adanya. (gambar 9)
Pada pameran berikutnya yaitu Sign and After Contemporary Islamic Art yang diadakan di Lawangwangi Bandung yang berlangsung pada tanggal 6 - 22 Agustus 2010, dikuratori oleh Rizki A. Zaelani yang mengelompokkan pendekatan artistik para seniman menjadi 4 kategori, pertama kelompok seniman yang menyatakan Al-Quran sebagai ikonografi dan sumber artistik, kedua, kelompok yang menampilkanbentukabstrak, ketiga,kelompok yang menggunakan kecenderungan abstraksi bentuk, dan keempat adalah kelompok yang menampilkan kecenderungan karya yang bersifat naratif dan figuratif. Pembagian kelompok berdasarkan kecenderungan artistik ini berkaitan dengan perayaan sikap estetik dan seni dari masing-masing seniman dalam khazanah kekayaan dan perubahan ekspresi seni demi membangun kesadaran diri yang digali dari tanda-tanda nilai kebesaran ciptaan sang khalik. Penelusuran sikap estetik dan seni ini dimulai dari kesadaran masingmasing seniman terhadap tanda-tanda artistik yang digeluti dalam tiap-tiap karya yang dikerjakannya. (Zaelani, 2010, hlm. 8). Dengan demikian setiap kecenderungan artistik seniman dalam mengintepretasikan nilai keislaman mendapat ruang yang luas untuk diimplemenatasikan dalam pameran ini. Apresiator dihadapkan pada pertanyaan mengenai bagaimana mencari nilai keislaman dari karya yang ditampilkan, yang tidak semuanya menampilkan ikon budaya Islam yang telah dikenal secara luas.

Dalam pameran ini tiap seniman dituntut untuk dapat memberi makna pada tiap-tiap tanda artistik yang ditampilkan, 
sehingga memberi ruang interpretasi yang baru bagi apresiator dalam memahami kandungan Islam yang terkandung pada tiap karya.

“Permasalahannya bagi para seniman adalah: tanda bagi makna apa yang bisa digunakan untuk mewakili sikap dan kepercayaan mereka sekaligus juga berlaku sebagai eskpresi seni rupa Islam." (Zaelani,2010, hlm. 10).

Merujuk pada tulisan kuratorial mengenai tujuan pameran ini adalah, Sign and After hendak menunjukkan relasi penting diantara aspek-aspek penciptaan serta kesadaran seni dnegan masalah kepercayaan (Islam).(ibid).

Di tahun berikutnya di Galeri Nasional Indonesia diadakan pameran Bayang : Pameran Seni Rupa Kontemporer Islami Indonesia, yang diselenggarakan oleh Pengurus Pusat Ikatan Alumni ITB (IAITB) dari tanggal 27 Juli hingga 14 Agustus 2011 dimana Rizki A. Zaelani dan A. Rikrik Kusmara ditunjuk menjadi kurator. Pada tulisan kurasi, kurator lebih menekankan pada makna 'Bayang' dalam konteks penciptaan citra (image) yang telah mempengaruhi kehidupan kita secara kultural hingga saat ini - baik kita alami dalam pengalaman ekspresi seni yang bersifat komunal (pertujukan wayang, iklan, hingga film) maupun kasus persoalan eskpresi seni yang bersifat personal (karya seni). (Zaelani, 2011, hlm. 17). Bila melihat karya peserta yang dipamerkan maka dari sisi tema sangat beragam, hampir sama dengan kecenderungan artistik pada pameran Sign and After di tahun 2010, walaupun dengan peserta yang lebih banyak dan beragam. Tema kaligrafi Islam tampaknya masih menjadi acuan dari tiap seniman dalam menginterpretasi konsep kurasi, demikian juga dengan intepretasi pemaknaan terhadap nilai Islam yang tercermin dalam berbagai obyek di kehidupan keseharian menjadi tema yang banyak ditampilkan.

Analisis tematik terhadap perkembangan sejarah seni lukis modern Indonesian bernafaskan Islam di Bandung sejak tahun 1970-an hingga tahun 2000an, menghasilkan kecenderungan tematik yang semakin beragam. Pada tahun 1970-an, dapat dikatakan sebagai tahun perintisan munculnya seni lukis modern Indonesia bernafaskan Islam di Bandung. Prinsip seni modern yang telah melekat pada diri Ahmad Sadali dan A.D. Pirous dijadikan kekuatan untuk menghadirkan nafas Islam dalam karyanya. Ahmad Sadali meneruskan abstrak lirisme dalam seni lukis modern dengan diisi oleh konsep Islam, sehingga memunculkan kecenderungan gaya seni lukis modern yang Islami yang membawa pada wilayah perenungan, yang ia perkenalkan dengan istilah abstrak meditatif. Adapun kaligrafi yang dihadirkan oleh Ahmad Sadali tetap menjadi suatu komposisi yang utuh dari abstrak meditatif yang membawa pada pesan tentang kefanaan.

Sementara itu, kekecewaan terhadap penolakan Barat pada para seniman modern non-Barat yang tidak diakui sebagai bagian dari seni modern yang universal, mendorong 
A.D. Pirous untuk kembali mencari sumbersumber ide yang berasal dari warisan budaya Islam yang lekat dengan kehidupannya. Sejak saat itulah karya A.D. Pirous lekat dengan kaligrafi Islam dan budaya Aceh. Kehadiran lukisan kaligrafi Islam menjadi gerakan seni tersendiri yang muncul di awal tahun 70-an dan mewarnai perkembangan seni modern di Indonesia. Kecenderungan untuk menghadirkan kaligrafi Arab dalam lukisan diikuti oleh pelukis lainnya, salah satunya adalah Abay D. Subarna, yang secara konsisten melukis kaligrafi hingga saat ini.

Sepanjang kurun waktu 1970-1990, perkembangan seni lukis modern Indonesia bernafaskan Islam masih didominasi oleh tema kaligrafi Arab yang digabungkan dengan gaya abstrak maupun dekoratif. Baru di penghujung tahun 1980-an, A.D. Pirous dan tim dari Decenta Bandung merancang sebuah kegiatan festival yang mampu menghadirkan keragaman budaya Islam nusantara, yaitu Festival Istiqlal.

Di awal tahun 1990-an, sebuah festival seni budaya Islam berskala nasional mulai dipersiapkan, dan di tahun 1991 dilaksanakan dengan nama Festival Istiqlal yang mewadahi beragam kegiatan yang berkaitan dengan budaya Islam, mulai dari pertunjukan, pameran, hingga simposium. Dampak paling penting dari penyelenggaraan festival ini adalah diselenggarakannya pameran seni lukis modern Indonesia bernafaskan Islam. Pada pameran ini 'nafas Islam' tidak hanya hadir dalam bentuk kaligrafi Arab, tetapi membuka cakrawala ekspresi estetik yang berkaitan dengan interpretasi keislaman dalam karya seni lukis.

Festival Istiqlal dapat dikatakan sebagai pencapaian tertinggi dari perkembangan seni Islam di Indonesia, hingga sekarang belum pernah ada lagi sebuah festival yang mampu menghadirkan keberagaman seni Islam secara menyeluruh dan diapresiasi hingga mancanegara. Pasca Festival Istiqlal tercatat beberapa kali upaya untuk membuat pameran setara itu, tetapi tidak pernah bisa dilaksanakan. Dukungan pemerintah serta partisipasi dari umat Islam saat itu membuat Festival Istiqlal I dan II dapat dilaksanakan dengan sukses, sekaligus berdampak pada perkembangan seni modern bernafaskan Islam di periode selanjutnya.

"Perkembangan seni spiritualisme tauhid (seni spiritual yang berdasarkan Islam) mencapai puncaknya dalam pergelaran Festifal Istiqlal tahun 1991 dan 1995. Dalam pergelaran ini tampil karyakarya seni spiritual dalam penafsiran personal yang beragam. Hal ini tampak dalam pemilihan rupa yang dimunculkan dalam karya tiap-tiap seniman. Meskipun gaungnya menghilang pada awal abad ke21, kecenderungan seni spiritual belum hilang dari medan seni Indonesia. Memang belum cukup kuat dari institusional dan lainnya, tetapi seni spiritual tetap merupakan salah satu alternatif dibandingkan seni sekuler yang dibawa oleh modernisme Barat" (Yustiono, 2002 )

Dampak paling terasa dari Festival Istiqlal adalah dimulainya pengklasifikasian seni lukis yang bernafaskan Islam Indonesia, yang kemudian menjadi acuan bagi 
pengklasifikasian tematik seni lukis modern bernafaskan Islam di masa selanjutnya. Pembagian 3 tema besar yaitu tema kaligrafi, representasional, dan non-representasional, menjadi acuan pengklasifikasian tema dalam seni lukis modern bernafaskan Islam. Hal itu terlihat pada penyelenggaraan pameranpameran seni modern bernafaskan Islam di tahun 2000-an, seperti pada pameran Islam and Identity:Islamic Modern \& Contemporary Art of Indonesia tahun 2009, dan yang lebih jelas pada pameran Sign and After Contemporary Islamic Art tahun 2010 yang mengklasifikasikan secara lebih terperinci, yaitu Teks Kaligrafi, Abstrak, Abstraksi Bentuk, dan terakhir Naratif dan Figuratif. Hal ini menunjukkan perekembangan tematik karya seni lukis modern bernafaskan Islam dapat dilakukan secara lebih terperinci. Bila pada pameran Festival Istiqlal pengklasifikasian tema ditarik ke wilayah yang paling umum, maka pada pameran Sign and After Contemporary Islamic Art diarahkan ke klasifikasi tematik yang lebih sempit disesuaikan dengan kecenderungan gaya yang dipakai oleh seniman.

Tahun 2011 hingga sekarang, belum terdapat pameran yang mengusung tema Islam sebagai tajuk utamanya, tetapi bukan berarti seniman muslim menjadi tidak produktif berkarya, justru 2 tahun belakangan kecenderungan seniman muda untuk menghadirkan nafas Islam dalam lukisannya semakin meningkat, hal ini bisa dilihat pada karya seniman muda yang menampilkan interpretasi terhadap Islam secara individual dan dipamerkan di ruang-ruang pameran seni kontemporer umumnya. Seperti pada tahun 1970-an ketika Ahmad Sadali dan A.D. Pirous berupaya menyerap nafas Islam yang kemudian dihadirkan kembali sesuai semangat jamannya, maka seniman muda sekarangpun melakukan hal yang sama. Tanpa terbelenggu pada 'seni Islam', mereka memamerkan karya mereka seperti layaknya karya seni lukis modern yang berkembang saat ini.

\section{PENUTUP}

Perkembangan seni lukis modern bernafaskan Islam Indonesia di Bandung periode 1970-2000an, yang dibagi dalam 4 periode, yaitu 1970-1980, periode 19801990, 1990-2000, dan 2000-2011, telah menghasilkan sebuah perubahan tematik dalam berkarya. Diawali tahun 1970, tema seni lukis bernafaskan Islam dimunculkan dalam bentuk abstrak meditatif dan lukisan kaligrafi, yang terus menjadi tema utama dalam lukisan bernafaskan Islam hingga akhir tahun 1980-an. Di tahun 90-an tema lukisan modern bernafaskan Islam mengalami perluasan merujuk pada kategorisasi kurator pameran seni rupa modern bernafaskan Islam di Festival Istiqlal, yaitu tema kaligrafi, representasional, dan non-representasional.

Pasca Festival Istiqlal, tepat ditahun 2000-an, perkembangan seni lukis modern bernafaskan Islam mengalami sedikit kemunduran, hanya terdapat beberapa pameran kecil yang menampilkan seni lukis kaligrafi Islam. Baru pada akhir tahun 2000-an, terjadi 4 pameran yang cukup representatif menghadirkan karya seni lukis modern bernafaskan Islam. Pada keempat 
pameran tersebut, terdapat perluasan tema yang disesuaikan dengan konteks kultural masyarakat saat ini dan yang kedua disesuaikan dengan kecenderungan artistik yang dilakukan oleh para seniman. Dengan demikian perkembangan seni lukis modern bernafaskan Islam Indonesia di Bandung bersifat sangat dinamis. Perubahan sosial budaya yang terjadi di masyarakat muslim menjadi perhatian utama para seniman muslim dalam menginterpretasikan nafas Islam, sehingga tema yang dihadirkan akan selalu mengalami perkembangan. Hal inilah yang menjadi salah satu penjelasan utama mengenai karakter seni bernafaskan Islam yang berbeda untuk tiap wilayah, sekaligus menjadi salah satu tantangan juga dalam merumuskan definisi seni bernafaskan Islam secara tegas.

\section{Daftar Pustaka}

\section{Artikel Jurnal}

Asher, Catherine B.,2015. Islamic Art History: Yesterday, Today, and The Future. Studies in Global Asias, Vol. I, No. I (Spring 2015), halaman 21-25, Penerbit University of Minnesota Press.

Dienaputra, Reiza D. (2012). Rekonstruksi Sejarah Seni Dalam Konstruk Sejarah Visual, Panggung, 22 (4) 1-16. Penerbit Sunan Ambu Press.

Shaw, Wendy M.K., 2012, The Islam in Islamic Art History: Secularism and Public Discourse, Journal of Art Historiography, Nomor 6, Juni 2012

Makalah Seminar

Choudhrey, Sara dan Ania Bobrowicz (2014). Shifting Boudaries: How to Make Sense of Islamic Art, The Arts Society Conference, 25-27 June 2014, Rome, Italy

\section{Buku}

Claus, Peter dan John Marriott, 2017, Historical An Introduction to Theory, Method and Practice, 2th Edition, London, New York, Routledge Taylor and Francis Group

George, Kenneth M., 2012, Melukis Islam Amal dan Etika Seni Islam di Indonesia, Bandung, Penerbit Mizan

George, Kenneth M. dan Mamannoor, 2002, AD. Pirous Vision, Faith and a Journey in Indonesian Art, 1995-2002, Bandung, Penerbit Serambi Pirous.

W.M., Abdul Hadi, 2000, Islam Cakrawala Estetik dan Budaya, Jakarta, Pustaka Firdaus.

Yustiono, 2002, Aspek-Aspek Seni Visual Indonesia, Identitas dan Budaya Massa: Gelombang Perang Spiritualisme Tauhid dan Pan-Sensualisme, Yogyakarta, Penerbit Yayasan Seni Cemeti.

\section{Katalog}

Ramli, Zaenudin, 2009, Islam dan Identity: Islamic Modern and Contemporary Art of Indonesia, Bandung, Penerbit ArtSociates

Zaelani, Rizki A., 2010, Sign and After Contemporary Islamic Art, Bandung, Penerbit ArtSociates

Zaelani, Rizki A. dan A. Rikrik Kusmara, 2011. "Bayang" Pameran Besar Seni Rupa Kontemporer Islami, Jakarta, Penerbit IA-ITB, Yayasan INISAF. 